\title{
HYPERPARATHYROIDISM IN KIDNEY DISEASE
}

\author{
By WALTER J. HIGHMAN, JR., AND BENGT HAMILTON \\ (From the Department of Pediatrics, University of Chicago, Chicago)
}

(Received for publication September 8, 1936)

Extensive investigations of the parathyroid glands were instigated by the cure of generalized osteitis fibrosa cystica by surgical removal of a parathyroid adenoma by Mandl (1) in 1925 . It was early noted that renal calculi were often found in cases of parathyroid tumor (2). Later work showed that these stones consisted chiefly of calcium phosphate and that the tendency to their formation was definitely decreased when the urine was made more acid (3). Removal of the parathyroid tumor. resulted in the disappearance of this tendency to calculus formation and of the alkalinity of the urine.

Albright, Baird, Cope, and Bloomberg (4), in their discussion of 83 cases of parathyroid tumor with hyperparathyroidism, brought out the fact that 43 of these showed clinical evidence of renal damage. These kidney lesions were attributed to damage resulting from the deposition of calcium in the renal parenchyma or to the formation of calculi in the pelves, such calcium depositions being manifestations of primary hyperparathyroidism. However, these authors suggested the possibility that parathyroid enlargement may be secondary to renal impairment: "It seems conceivable therefore that a chronic renal insufficiency with phosphate retention and a high inorganic phosphorus level might likewise cause hyperplasia of all parathyroid tissue which might go on to multiple tumor formation" and later, "In these cases the kidney damage may be the cause and not the result of the parathyroid tumors."

Bergstrand (5) studied the parathyroid glands in an extensive series of autopsies, and in most of the cases where he found them enlarged, there was also some damage to the kidneys. Pappenheimer and Wilens (6) carefully weighed the parathyroid glands from a large series of necropsies. They found the parathyroids taken from unselected nephritics to average more than 50 per cent greater in weight than those taken from non-nephritic controls. Seven severe nephritics showed an increase of 109 per cent over the same control series. The enlargement was diffusely hyperplastic in character, resembling the enlargement which has been reported in rickets $(7,8)$, and which may exist in pregnancy $(9,10)$. Adenomata were found in only three of 56 nephritics and in two of 74 controls. Jarrett, Peters, and Pappenheimer (11) report that they have induced a similar enlargement of the parathyroids by producing chronic renal insufficiency in rats.

In previous reports from this laboratory evidence of functional hyperactivity of the parathyroid glands in rickets (12) and in pregnancy (13) has been presented. We have used the same approach in our investigation of parathyroid activity in the present series of nephritic patients, ${ }^{1}$ to determine whether the hyperplasia noted by Pappenheimer and Wilens (6) is accompanied by a hyperfunction. The patients were selected on the basis of elevation of the blood urea nitrogen, most of them having chronic rather than acute renal insufficiency. The controls were thirtyeight normal persons-thirty women and eight men. Determinations of calcium and phosphorus were usually done on the same samples of blood which were used for the experimental work.

\section{METHODS}

Serum calcium was determined by the method of Fiske and Logan (14). Serum phosphorus was determined by the method of Fiske and Subbarow (15). The method of Hamilton and Schwartz (16), slightly modified (17), was used to detect hyperactivity of the parathyroid glands. This method consists of measuring the rise of the serum calcium of a rabbit into which $30 \mathrm{cc}$. of the patient's blood have been injected intramuscularly. Calcium chloride is given the rabbit by stomach tube immediately after injection and one, three, and five hours later. Blood is drawn from

1 The authors gratefully acknowledge the cooperation of Dr. Andrew J. Brislen, Dr. Edward J. Stieglitz, and Dr. Louis Leiter in obtaining material for this study. 
the rabbit before beginning the test and seven minutes after each of the last two administrations of calcium chloride. A rise of $0.30 \mathrm{mM}$. calcium or more per liter of rabbit serum is taken as indicative of an abnormally large amount of parathyroid hormone in the injected blood.

\section{RESULTS}

Blood from each of 23 nephritic patients was injected into rabbits, and the rise of the serum calcium of the rabbits was determined. The blood of all but three of these 23 patients produced a rise of more than $0.30 \mathrm{mM}$. calcium per liter of rabbit serum, which indicates that more than normal amounts of parathyroid hormone were present in the injected blood. The results of these parathyroid function tests are shown in Table I, together with the other data on the com-

TABLE I

Parathyroid function tests, blood constituents and arterial tensions

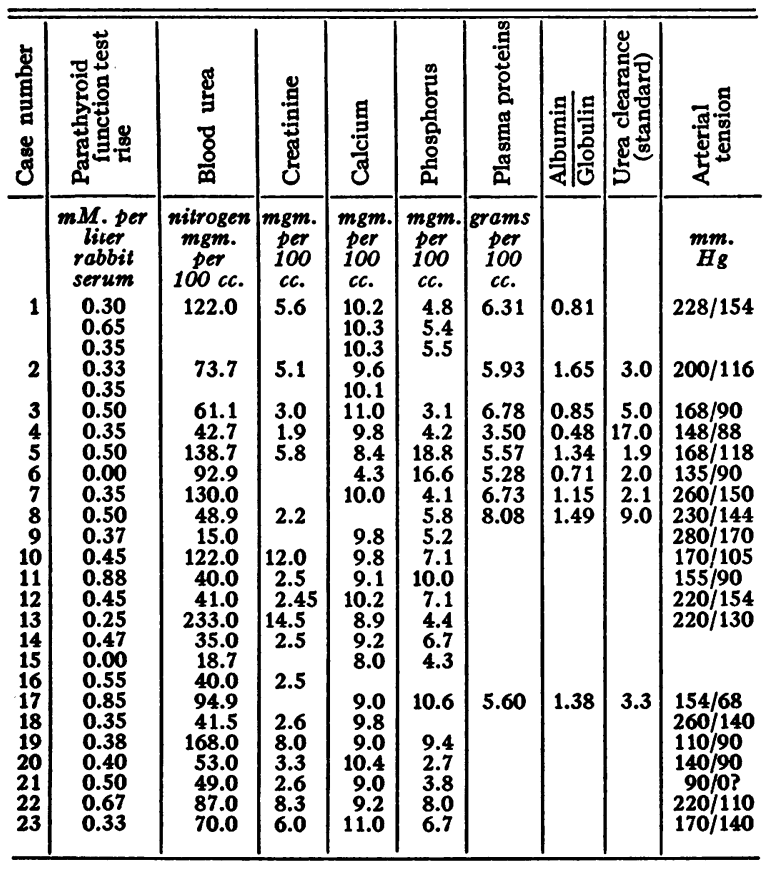

position of the blood and on the arterial tension. Where more than one determination of a blood constituent was made, that which was done at the date nearest to the performing of the parathyroid function test was tabulated. Of the 38 controls all but three showed rises of less than $0.10 \mathrm{mM}$. calcium per liter of rabbit serum, and none was higher than 0.23. A comparison of the normal and the nephritic series is made in Table II. It

TABLE II

Parathyroid function test in normal persons and in nephritic patients

\begin{tabular}{|c|c|c|}
\hline $\begin{array}{l}\text { Rise in rabbit } \\
\text { serum calcium }\end{array}$ & $\begin{array}{c}\text { Normals- } \\
\text { number of } \\
\text { persons }\end{array}$ & $\begin{array}{c}\text { Nephritics- } \\
\text { number of } \\
\text { patients }\end{array}$ \\
\hline $\begin{array}{l}m M . \text { per liter } \\
0.00 \text { to } 0.09 \text {. } \\
0.10 \text { to } 0.19 \\
0.20 \text { to } 0.29 \\
0.30 \text { to } 0.39 \\
0.40 \text { to } 0.49 \\
0.50 \text { to } 0.59 \\
0.60 \text { and up. }\end{array}$ & $\begin{array}{lr}\ldots & 35 \\
\ldots & 1 \\
\ldots & 2 \\
\ldots & \\
\ldots & \\
\ldots & \\
\ldots & \end{array}$ & $\begin{array}{r}2 \\
1 \\
10 \\
4 \\
5 \\
4\end{array}$ \\
\hline & 38 & $26^{*}$ \\
\hline
\end{tabular}

* Three tests were performed on Case 1 and two on Case 2.

is obvious from the figures in Table $I$ that there is no direct correlation between the degree of hyperactivity of the parathyroid glands, as measured by this procedure, and the amount of elevation of the serum phosphorus; nor is there a direct relationship between the parathyroid activity and the blood urea nitrogen. However, the correlation between increased parathyroid activity and chronic nephritis is clear cut.

In order to exclude the possibility that some of the substances which are present in the blood of uremic patients in more than normal amounts were the direct cause of the effect on the blood calcium of the rabbit, $30 \mathrm{cc}$. of a solution containing the following substances were injected intramuscularly into each of four rabbits: urea, 200 mgm. per 100 cc.; uric acid, 10 mgm. per 100 cc.; creatinine, $5 \mathrm{mgm}$. per $100 \mathrm{cc}$; sodium carbonate, $5 \mathrm{mgm}$. per $100 \mathrm{cc}$; cystine, $10 \mathrm{mgm}$. per 100 cc.; sodium chloride, $900 \mathrm{mgm}$. per $100 \mathrm{cc}$. The same technique was followed as in the tests for parathyroid hormone. None of these rabbits showed a positive test.

\section{DISCUSSION}

As has been suggested by Pappenheimer and Wilens (6), "It is probable that the cases with severe clinical nephritis had phosphate retention, and since any increase in $\mathrm{PO}_{4}$ ions will decrease the amount of $\mathrm{Ca}$ ions in the blood (Thomson 
and Collip (18)) this may incite the parathyroids to increased activity and overgrowth." Since parathyroid hormone tends to elevate blood calcium, hyperfunction of the parathyroids in this instance would constitute a defense against hypocalcemia.

We have shown that there is no proportionality between the increase in parathyroid function and the rise of the inorganic phosphorus of the serum in nephritis; but inasmuch as the phosphorus was generally elevated in the cases which showed increased parathyroid function, our data are not in discord with the theory proposed by the above authors. However, one patient in our. series (Case 6, Table I) had developed high arterial tension, albuminuria, and convulsions during pregnancy one and one-half years before the last admission, and had delivered a stillborn child. On the last admission she showed no evidence of parathyroid hyperactivity; the serum phosphorus was extremely high; and the serum calcium in this case alone was below the tetany level. Two weeks after. admission in uremia she developed convulsions and died a week later, showing signs of pulmonary edema and shock. Here we may assume that the lack of compensatory parathyroid hyperfunction allowed a profound imbalance of the calcium metabolism.

The failure to elicit an elevation of the rabbits' blood calcium by the injection of the solution containing certain constituents of uremic blood indicated that these substances in uremic blood are not responsible for the reaction. This experiment, however, does not in any way eliminate the possibility that other substances in uremic blood are responsible for the rise.

We agree with the hypothesis of Pappenheimer and Wilens that the hyperphosphatemia of renal insufficiency is the initiating factor in the chain of events which leads to parathyroid hyperplasia. We have shown, moreover, that the hyperplasia demonstrated by the above authors is accompanied by hyperfunction. It is conceivable that this increase in parathyroid activity constitutes a biological defense against impending hypocalcemia secondary to phosphate retention.

\section{CONCLUSION}

There is increased activity of the parathyroid glands in chronic renal disease, as measured by the method of Hamilton and Schwartz (16).

\section{BIBLIOGRAPHY}

1. Mand1, F., Klinisches und Experimentelles zur Frage der lokalisierten und generalisierten Osteitis fibrosa. Arch. f. klin. Chir., 1926, 143, 245.

2. Literature reviewed by Albright, Baird, Cope, and Bloomberg (4).

3. Albright, F., and Bloomberg, E., Hyperparathyroidism and renal disease, with a note as to the formation of calcium casts in this disease. $J$. Urol., 1935, 34, 1.

4. Albright, F., Baird, P. C., Cope, O., and Bloomberg, E., Studies on the physiology of the parathyroid glands. IV. Renal complications of hyperparathyroidism. Am. J. M. Sc., 1934, 187, 49.

5. Bergstrand, H., Parathyreoideastudien. II. Über Tumoren und hyperplastische Zustände der $\mathrm{Ne}$ benschilddrüsen. Acta med. Scandinav., 1920-21, 54, 539.

6. Pappenheimer, A. M., and Wilens, S. L., Enlargement of the parathyroid glands in renal disease. Am. J. Path., 1935, 11, 73.

7. Erdheim, Denkschr. d. k. Akad. d. Wessensch. MathNaturw. Klasse, Wien, 1914, 90, 363-cited from Ritter (9).

8. Pappenheimer, A. M., and Minor, J., Hyperplasia of the parathyroids in human rickets. J. Med. Research, 1921, 42, 391.

9. Ritter, C., Über Epithelkörperchenbefunde bei $\mathrm{Ra}$ chitis und anderen Knochenerkrankungen. Frankfurt. Ztschr. f. Path., 1920, 24, 137.

10. Seitz, L., Eklampsie und parathyreoidea. Arch. f. Gynäk., 1909, 89, 53.

11. Jarrett, W. A., Peters, H. L., and Pappenheimer, A. M., Parathyroid enlargement in rats following experimental reduction of kidney substance. Proc. Soc. Exper. Biol. and Med., 1935, 32, 1211.

12. Hamilton, B., and Schwartz, C., Rickets and Hyperparathyroidism. Am. J. Dis. Child., 1933, 46, 775.

13. Hamilton, B., DaSef, L., Highman, W. J., Jr., and Schwartz, C., Parathyroid hormone in the blood of pregnant women. J. Clin. Invest., 1936, 15, 323.

14. Fiske, C. H., and Logan, M. A., The determination of calcium by alkalimetric titration. II. The precipitation of calcium in the presence of magnesium, phosphate, and sulfate, with applications to the analysis of urine. J. Biol. Chem., 1931, 93, 211.

15. Fiske, C. H., and Subbarow, Y., The colorimetric determination of phosphorus. J. Biol. Chem., $1925,66,375$.

16. Hamilton, B., and Schwartz, C., A method for the determination of small amounts of parathyroid hormone. J. Pharmacol. and Exper. Therap., 1932, 46, 285.

17. Hamilton, B., and Highman, W. J., Jr., A test for abnormally large amounts of parathyroid hormone in the blood. J. Clin. Invest., 1936, 15, 99.

18. Thomson, D. L., and Collip, J. B., The parathyroid glands. Physiol. Rev., 1932, 12, 309. 